\title{
DNA Endonuclease RBBP8
}

National Cancer Institute

\section{Source}

National Cancer Institute. DNA Endonuclease RBBP8. NCI Thesaurus. Code C73442.

Retinoblastoma binding protein 8 (897 aa, $102 \mathrm{kDa}$ ) is encoded by the human RBBP8 gene. This protein is involved in cell cycle checkpoint control. 